\title{
ТЕХНОЛОГИИ НUGНЕS в глобальном и региональном аспектах
}

л.Павлова

DOI: $10.22184 / 2070-8963.2019 .81 .4 .66 .67$

Традиционно на 22-м по счету ежегодном технологическом семинаре Hughes Network Systems обсуждались региональные и глобальные аспекты деятельности компании, ее планы на нынешний год, перспективы развития рынка спутникового ШПД в России.

Hughes - это компания, которая создает технологии спутниковой связи и продвигает их по всему миру. Ежегодно на НИОКР она тратит порядка 50 млн долл., каждый год подтверждает порядка 30 патентов, всегда имея при этом 150 патентов в процессе регистрации и утверждения. Немногие компании могут представить такие результаты, заметил на семинаре Константин Ланин, региональный директор Hughes в России и СНГ.

Он напомнил, что Hughes Network Systems - крупнейший в мире поставщик технологических решений в области широкополосных спутниковых систем для домашнего и корпоративного использования. Основные услуги СШПД предоставляются в рамках спутниковой сети HughesNet, обслуживающей более 1,3 млн индивидуальных пользователей и корпоративных клиентов в Северной и Южной Америке.

"Безусловно, сети индивидуальных пользователей имеют для Hughes преимущественное значение, поскольку сегмент потребительского рынка в компании самый значительный, - подчеркнул К.Ланин. - Основной драйвер этого рынка - видеоконтент, и умение оптимизировать его, доставлять до абонента с требуемым качеством является нашим неоспоримым преимуществом. При этом сервисные планы на сегодняшний день в Северной и Латинской Америке составляют 25 Мбит/с на загрузку и 3 Мбит/с в обратном канале".

Яркий пример развития рынка индивидуальных пользователей СШПД высокими темпами продемонстрировала Бразилия: за два года абонентская база превысила 100 тыс., а в январе 2019 года Hughes do Brazil вышел на уверенное включение 10 тыс. абонентов в месяц. По словам К.Ланина, объясняется это тем, что в Бразилии была полностью скопирована модель бизнеса в Северной Америке, когда Hughes не продает оборудование, а оставляет его за собой и берет 50 долл. за первоначальную установку. При этом действует система стимуляции партнеров: с каждой установленной станции партнер получает один доллар в месяц. Кроме того, не имея никакой рекламы на телевидении и никакой господдержки, продавцы станций фактически стучатся в каждую дверь и рассказывают об услуге - оказалось, что это самое эффективное средство получения результата. Теперь опыт Бразилии Hughes переносит на другие страны Латинской Америки - Колумбию, Мексику, Перу, Эквадор, Чили.

Российский сегмент индивидуальных пользователей СШПД, надо признать, все еще не стал массовым, в целом он состоит примерно из 30 тыс. абонентов (терминалов Hughes - более половины). "Наверное, нам нужно набрать 50 тыс. - и это станет той критической массой, которая позволит всколыхнуть рынок и двигаться дальше", - считает К.Ланин.

Услуги СШПД компания предоставляет через систему JUPITER, которая является наиболее широко используемой в мире платформой для работы через спутники высокой пропускной способности (HTS). Технология может работать в диапазонах C, Ku, Ka, поддерживая широкий диапазон разнообразных широкополосных приложений для корпораций, мобильной связи, магистральных каналов сотовой связи. На сегодняшний день суммарный объем выполненных заказов превышает 7 млн периферийных терминалов Hughes, поставленных более чем в 100 стран мира, что представляет около 50\% мирового рынка. Эта технология 
является основой широкополосных услуг для авиалайнеров по всему миру. По словам К.Ланина, в настоящее время более тысячи самолетов летают с терминалами Hughes. В России в прошлом году был введен в эксплуатацию на площадке ГK AltegroSky в Медвежьих Озерах новый шлюз JUPITER для сети GEE/Air France.

В нынешнем году компания ожидает в России развития проекта создания сети СШПД в Ка-диапазоне. "Как один из драйверов рынка, этот проект будет набирать обороты, - считает К.Ланин. - Кроме того, Казахстан и Азербайджан объявили о программах цифровой экономики. В Азербайджане мы ввели в эксплуатацию шлюз JUPITER-2 на спутнике "Азерсат-1" с возможностью расширения на второй спутник "Азерсат-2". Идут тестирования по проектам министерств иностранных дел. В прошлом году мы реализовали усилиями нашего офиса один из глобальных проектов ООН для подразделения СТВТО, которое занимается контролем за ядерными испытаниями по всему миру. С помощью партнеров мы подключили к проекту станции России, Казахстана, Азербайджана, Украины, Таджикистана, Туркменистана, Узбекистана. Hughes подписал глобальный проект с ООН на следующие 10 лет".

Над территорией Америки сейчас задействованы четыре спутника, так называемые "Юпитер-1" и "Юпитер-2", Hughes 63W и Hughes 65W с суммарной пропускной способностью 400 Гбит/с. В 2021 году запланирован запуск на орбиту спутника "Юпитер-3". С его появлением пропускная способность превысит 1 Тбит/с, а минимальный сервисный план будет составлять 100 Мбит/с на абонента.

По словам директора по продажам регионального подразделения Hughes Юрия Фомина, компания непосредственно участвует в самом первом проекте по строительству сетей СШПД в Ка-диапазоне на российских спутниках "Экспресс-АM5" и "Экспресс-АM6". В рамках данного проекта Hughes не только построил шлюзы, но и продолжает совершенствовать систему исходя из запросов заказчика и текущей рыночной ситуации. В настоящее время в основном завершился процесс обновления программного обеспечения системы, конечной целью которого является расширение ее возможностей за счет максимальной унификации с одноименной системой второго поколения, включая поддержку периферийного оборудования. В результате реализации сложного комплекса организационных и технических мероприятий в первом квартале инженерами компании обеспечена поддержка периферийного оборудования нового поколения и, в частности, терминалов НТ2000. Терминал НТ2000 внешне не сильно отличается от уже широко известного НТ1100, однако значительно превосходит своего предшественника по возможностям, в том числе: в два раза по пропускной способности и в четыре раза по производительности. Все это дает возможность оператору повысить как количественные, так и качественные показатели предлагаемых пользователям услуг без увеличения капитальных затрат на оборудование.

На сегодняшний день система "Юпитер" нового поколения поддерживает два типа обратных каналов: MF-TDMA и TDM. Каналы с частотно-временным уплотнением обеспечивают скорость несущих от 256 ксим/с до 12 Мсим/с, с модуляциями OQPSK, 8PSK, 16APSK и помехоустойчивым кодированием LDPC. Отличительной чертой обратных каналов с ЧВУ является динамическая инкапсуляция IP-пакетов с поддержкой пакетных блоков переменной длины, обеспечивающей высокую эффективность утилизации ресурсов канала благодаря оптимизации размера кадра передаваемых данных под выделяемую полосу, а также система "адаптивного выбора обратного канала" AIS, обеспечивающая максимальную пропускную способность при заданном коэффициенте готовности (за счет динамического выбора оптимальной мощности передатчика, скорости кодирования, символьной скорости и модуляции в зависимости от текущего состояния радиоканала). Обратные каналы TDM стандарта DVB-S2X позволяют строить выделенные линии связи сопоставимые по качеству с традиционными решениями SCPC. Такие каналы рекомендуется использовать прежде всего в сетях сотовой и транкинговой связи при необходимости обеспечения гарантированных скоростей и качества в течение достаточно длительного периода времени.

Основные новшества функционала системы в 2019 году - это, прежде всего, поддержка новой схемы многостанционного доступа на основе скремблированного разделения каналов, балансировка загрузки прямых и обратных каналов, поддержка L2. Новая схема многостанционного доступа SCMA позволяет существенно сократить время отклика для HTTPS трафика, а также оптимизировать загрузку каналов при подключении "точек продаж" и банкоматов. Поддержка больших пакетов т.н. Jumbo Frames до 9000 байт актуальна для работы с MPLS-сетями и сотовыми операторами и поддерживается терминалами НТ2550 и НТ2650, ориентированными на этот сегмент.

Как отметил К.Ланин, чтобы эффективно обслуживать амбициозные сервисные планы Заказчиков, Hughes постоянно совершенствует свою линейку оборудования и увеличивает производительность терминалов: "Мы постоянно предлагаем что-то новое - это проактивные действия компании, направленные на повышение удовлетворенности клиента". 